abundant and varied near White Island, about $29 \mathrm{~km}$ south of McMurdo Station, at least near the edge of the shelf. The idea of abundant and flourishing under-ice life near White Island is supported by the presence of well-nourished Weddell Seals (Leptonychotes weddelli).

Accordingly scientists from Scripps Institution of Oceanography, La Jolla, California, headed by Dr Paul Dayton, will study the relationship between sea animals and their environment in McMurdo Sound, both under and outside the Ross Ice-shelf. The near-bottom communities under the ice live in habitats ranging from shallow water to deep sea, with varying currents and different types of sediments. The research workers will take underwater photographs of the near-bottom environments in waters ranging from 18 to $457 \mathrm{~m}$ deep at seven sites near Ross Island, three of the sites being under the ice-shelf. They also will use underwater photographs to survey rapidly-swimming near-surface life-forms in McMurdo Sound and under the Ross Ice-shelf.

The behaviour, brooding, and foraging patterns, of King Penguins (Aptenodytes patagonica) will be studied by other scientists, also from Scripps Institution, to determine the energy expended by the birds during those processes. In collaboration with British biologists on South Georgia Island, the research workers will monitor the activities of the birds while they care for their older chicks, and will study their behaviour while they make trips to sea.
The US scientists, led by Dr Gerald L. Kooyman, will record the birds' number, depth, and frequency, of dives; the time spent swimming, diving, and out of water; and the rate and distances of swimming. To measure the energy expended, the scientists will use water labelled with two different tracer-isotopes in determining water turnoverrates inside the King Penguins, and also their carbon dioxide production. While conducting the studies, they will measure the average metabolic rate for the birds on the Island and at sea.

Penguins comprise from $75 \%$ to $85 \%$ of the birds in southern-ocean ecosystems. The King Penguin is a species that is common on sub-antarctic islands but is rarely found on the Antarctic Continent. Individuals average between 10 and $18 \mathrm{~kg}$ and stand about $76 \mathrm{~cm}$ high.

Few studies have been made of King Penguins even though they are the major predators in that region's ocean food-web, feeding on fish and squid. Data gathered by the South Georgia Island group should make possible the development of improved models of the impact which the Penguins make on the ecosystems involved, and so lead to improved understanding of how these animals exploit their environment.

RALPH KAZARIAN
National Science Foundation
1800 G Street
Washington
DC 20550, USA.

RALPH KAZARIAN $1800 \mathrm{G}$ Street

DC 20550, USA

\title{
Global Environmental and Resource Assessment to be Published Annually by Two Research Concerns
}

Beginning early in 1986, an annual report on world environmental and resource trends will be published jointly by two respected international study-centres - the World Resources Institute (WRI) in Washington, DC, and the International Institute for Environment and Development (IIED) in Washington and London. This World Resources Report will be the first such major effort to provide, on a continuing basis, the best and most up-to-date information on world resource conditions and trends. In addition, the report will offer analyses of special issues; roundups of information on current research, conferences, publications, and special events; and a comprehensive set of environmental and resource data indicators.

The report will review the following areas regularly each year: population, human settlements, food and agriculture, forests and rangelands, wildlife, energy, fresh water, oceans and coasts, atmosphere and climate, global systems and cycles, and policies and institutions.

According to Gustave Speth, president of WRI, 'We saw a need for a periodic report that would focus public attention directly on global and regional resource-issues; a report that would provide a vehicle for the communication of ideas, analyses, and new data; and one that would help shape the continuing debate on resource use and environmental problems. If you believe-as we do-that world resource issues are crucially important to the future of our society and to the Earth's inhabitants, then it follows that policymakers, in and out of government, and the world community at large, all need the best information available to deal with them. We intend this report to help provide that information.'

David Runnalls, the vice-president of IIED, said, 'The World Resources Report will be a vital tool for everyone concerned with the management of physical and natural resources and the environment-[ranging] from food production to energy supply and to the condition of third- world mega-cities. In time we expect the report to become the almanac for everyone in this vast field.'

The World Resources Report will be edited by Donald Hinrichsen, former Editor of Ambio, an international environmental journal published by the Royal Swedish Academy of Sciences. Hinrichsen joins Managing Editor Daniel Tunstall, who was the principal author of the US Council on Environmental Quality's report, Environmental Trends.

Dr Monkombu S. Swaminathan, Director-general of the International Rice Research Institute in the Philippines, is Chairman of the Report's Editorial Advisory Board, which has recently been formed. The Board's international membership includes ten individuals representing diverse experiences in government, business, science, and research.

Funding for the World Resources Report comes from WRI and IIED, with additional support from the Ford Foundation, the J. N. Pew, jr, Charitable Trust, the United Nations Environment Programme, the German Marshall Fund of the United States, the William and Flora Hewlett Foundation, the UN Development Programme, and the World Bank.

The World Resources Institute is an independent centre for non-partisan policy research on resource and development issues of global significance. The International Institute for Environment and Development is an international organization that conducts non-partisan policy research, informs and educates the public, and provides technical assistance to developing countries on the relationship between environment, development, and human needs.

William J. Lanouette, Communications Director World Resources Institute

1735 New York Avenue, $N W$

Washington

DC 20006, USA. 